\title{
East-coast Australian gas markets - overcoming the lumpiness of capital allocation and temporal instability
}

\begin{abstract}
Australia's east-coast gas market has undergone significant transformation in the past decade. The discovery of non-conventional coal-seam gas reserves led to investment in three 'lumpy' LNG export facilities in Gladstone, Queensland. Drilling activity has subsequently slowed, a direct result of an unexpected 'soft' global price for $L N G$. This slowdown, in an environment of a tripling of east-coast gas demand, has resulted in concerns about domestic gas shortages. To be clear, there is no lack of gas resources. Instead, the problem relates to the relative lumpiness of capital allocation and temporal instability driven by changing global circumstances. Utilising a simple theoretical partial equilibrium framework, various options for overcoming these problems are assessed. Of these options, developing import infrastructure appears to be a 'no regrets' option that would ensure that the price floor, the LNG netback price, also becomes the market price cap.
\end{abstract}

Keywords: energy; gas markets; LNG; partial equilibrium JEL Codes: D04, D47, Q40, Q41, Q48

\section{Introduction}

The Australian east-coast gas market has been transformed by the development of significant $2 \mathrm{P}^{1}$ coal-seam gas reserves and a Liquefied Natural Gas (LNG) export industry in Queensland. Domestic east-coast gas pricing is now linked to international LNG pricing for the first time. There are now persistent concerns about potential gas shortages, higher domestic gas prices and unavailability of supply contracts with reasonable tenors (see AI Group, 2017, and De Silva et al, 2016). Simshauser and Nelson (2015a, 2015b) concluded that the east-coast of Australia could face 'unmet gas demand' from 2016. More recently, the Australian Energy Market Operator (AEMO) concluded that gas shortfalls of between 54 Petajoules (PJ) and 107 Petajoules (PJ) per annum (up to around 15\% of domestic demand) could occur from 2018 (AEMO, 2017).

At least five alternative 'solutions' have been proposed over several years: the introduction of an east-coast domestic gas reservation policy; utilisation of a 'National Interest Test' for new LNG export projects; expanding domestic gas supply through the removal of moratoria on coal-seam gas extraction; developing pipeline capacity 'linking' the east-coast and west-coast gas markets; and construction of LNG import facilities. Neill (2017) comprehensively demonstrates the net economic costs associated with the introduction of a domestic gas reservation policy. A 'National Interest Test' is worth considering but is unlikely to have any impact in the medium term given no new LNG export facilities are being considered on Australia's east coast.

\footnotetext{
${ }^{1} 2 \mathrm{P}$ is an industry term used to denote gas that is likely to be extractable given existing technology and commercial circumstances.
} 
For the purposes of this article, the 'problem' facing policy makers is overcoming limitations of domestic gas supply on Australia's east-coast. Potential solutions need to be assessed for their robustness in environments of both comparatively high and low international LNG pricing as outcomes are not uniform in these two pricing scenarios. The purpose of this article is therefore to consider: the Australian Domestic Gas Security Mechanism; expanding domestic supply; linking the east-coast and west-coast markets by pipeline; and the development of LNG import capability as potential solutions to shortfalls of natural gas supply in the east-coast market, in scenarios of both comparatively high and low international LNG pricing. Section 2 provides a quantitative overview of the problem facing the east-coast gas market. Simple partial equilibrium theory is presented in Section 3 to critically assess potential solutions. The various proposed solutions are considered in Section 4 with concluding remarks and brief policy recommendations provided in Section 5.

\section{Overview of the problem}

At the turn of the century, there was concern that Australia's east-coast would suffer significant shortfalls of natural gas. ${ }^{2}$ But with the development of new drilling technologies, large resources of coal-seam gas were unlocked and 2P reserves increased substantially from 3,400 PJ in 2005 to approximately 49,300 PJ today. With historical annual domestic gas demand of around 600-700 $\mathrm{PJ}$ per annum, the ratio of $2 \mathrm{P}$ reserves to domestic demand increased substantially from around 5 years to 75 years of supply. An overview of reserves is presented in Table 1.

Table 1: Australian east-coast reserves

\begin{tabular}{c|c}
\hline Category of Reserve & Reserves (PJ) \\
\hline Developed 2P & 10,151 \\
Undeveloped 2P & 39,166 \\
2C & 56,429 \\
Potential resources & 151,867 \\
\hline
\end{tabular}

As a consequence of the development of such significant gas reserves, three large LNG export facilities were developed at Gladstone in Queensland. The projects are known as QCLNG, APLNG and GLNG. These facilities can consume around 1,450 PJ per annum. Around 95\% of the rated output of the LNG trains is forward contracted and the contracts are understood to be at least 20 years in length. ${ }^{3}$ Over this period of operation, this is expected to result in around 30,000 $\mathrm{PJ}$ of gas consumption. It should be noted that this development was a rational economic response to the existence of such vast quantities of reserves compared with relatively small domestic demand. It represented the only way of monetising the reserves in a timely manner. A summary of the LNG projects is presented in Table 2 .

Table 2: East-coast LNG projects ${ }^{4}$

\begin{tabular}{c|c|ccc|c|c}
\hline Project & Operator & $\begin{array}{c}\text { Project } \\
\text { Announcement }\end{array}$ & $\begin{array}{c}\text { Max. } \\
\text { Capacity } \\
\text { (PJ/annum) }\end{array}$ & $\begin{array}{c}\text { Contracted } \\
\text { Supply } \\
\text { (PJ/annum) }\end{array}$ & $\begin{array}{c}\text { Train 1 } \\
\text { Commissioning }\end{array}$ & $\begin{array}{c}\text { Train 2 } \\
\text { Commissioning }\end{array}$ \\
\hline QCLNG & Shell & Oct 2010 & 549 & 474 & Dec 2014 & Jul 2015 \\
APLNG & Origin & July 2011 & 575 & 510 & Jan 2016 & Oct 2016 \\
GLNG & Santos & Jan 2011 & 498 & 427 & Sep 2015 & May 2016 \\
\hline Total & \multicolumn{7}{|c|}{ Source: Industry reports } & & \\
\hline
\end{tabular}

\footnotetext{
${ }^{2}$ In fact, considerable investment was made on front-end engineering and design (FEED) for a pipeline to connect vast reserves of natural gas in Papua New Guinea to the east-coast Australian market.
} 


\footnotetext{
${ }^{3}$ QCLNG has contracted its gas to CNOOC, Shell, Tokyo Gas and Chubu Electric. GLNG has contracted its gas to Petronas and Kogas. APLNG has contracted its gas to Sinopec and Kansai Electric. GLNG has indicated that it will only be producing around $85 \%$ of its contracted volume until the 2020s (see Chambers, 2017). It is understood that QCLNG has more flexibility as its contracts are supplied from the Shell LNG portfolio, rather than being directly linked to the QCLNG project.

${ }^{4}$ One further project, utilising Arrow's CSG reserves, was also proposed but ultimately shelved. See

http://www.smh.com.au/business/shell-shelves-arrow-lng-project-in-queensland-20150129-131sqe.html, accessed online 17 November 2017.
} 
The development of an LNG export industry has resulted in a tripling of annual demand for natural gas and produced \$120 billion in investment across Australia (see Jacobs, 2011 and Christie et al, 2011). But there is now concern about potential gas shortages and significant public commentary about high prices driven by supply scarcity. However, it is important to note that the issues largely relate to the lumpiness of capital allocation and temporal instability. In this author's view, concerns should not relate to where there are sufficient resources to meet demand.

Australia's very significant east-coast gas resources are shown in an aggregate supply curve in Figure 1.

Figure 1: Aggregate supply curve for gas resources in east-coast Australia

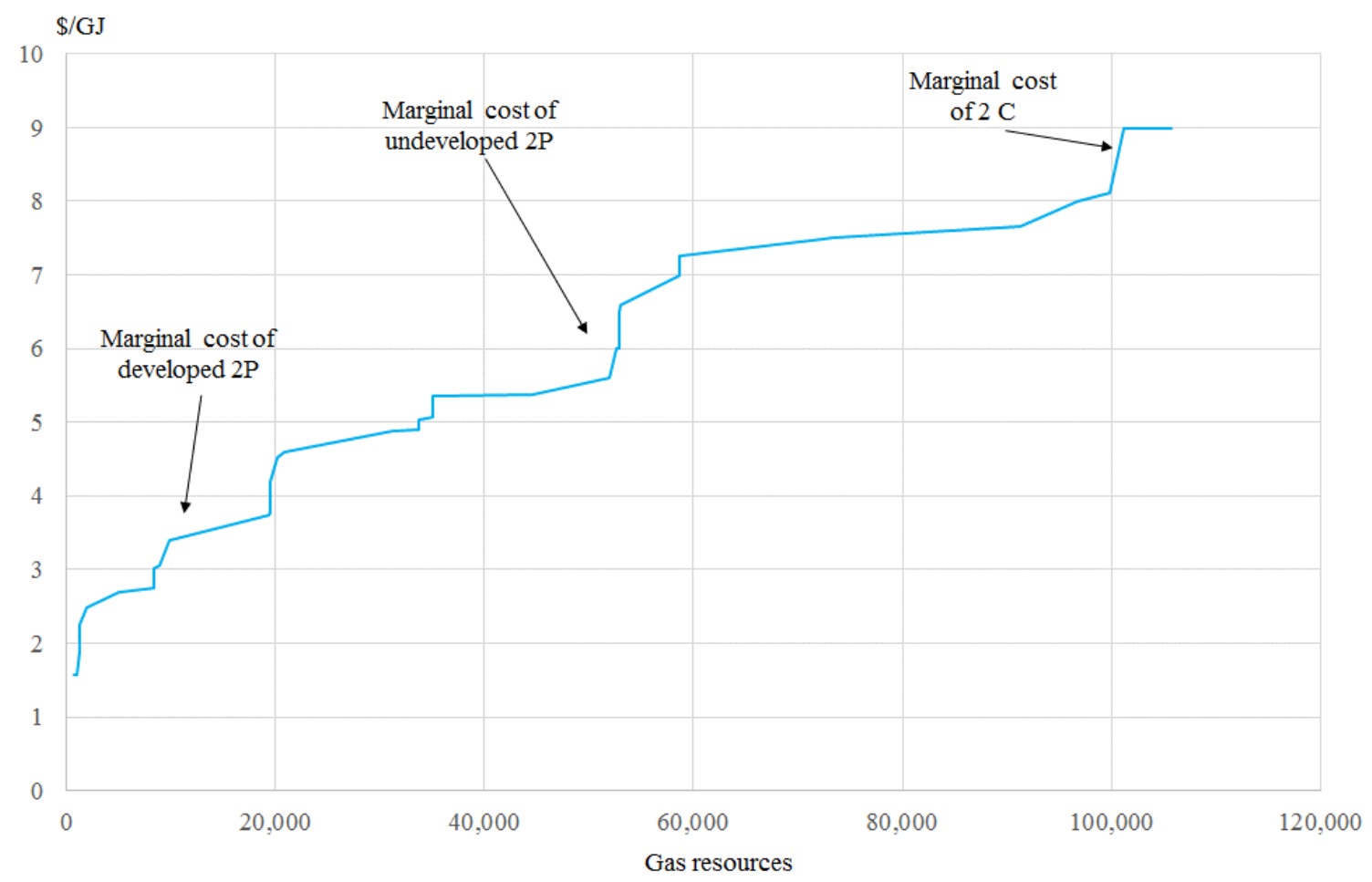

Source: Compiled using data from AEMO (2017) and company sources

Figure 1 shows an aggregate gas supply curve for east-coast Australia. There is more than enough gas to physically satisfy domestic demand and current LNG export contracts for at least twenty years. There are around 50,000 PJ of 2P reserves with both domestic and LNG consumption summing to around 45,000 PJ. The estimated marginal cost of production for these resources is around \$6/Gigajoule (GJ). Beyond this point there is a significant step-change in estimated costs with a range of between $\$ 7 / \mathrm{GJ}$ and $\$ 9 / \mathrm{GJ}$. This is an important observation as it represents a material deviation from historical pricing of closer to $\$ 3 /$ GJ. Prior to the development of coalseam gas, much of east-coast demand was met from conventional supplies in the Gippsland and Moomba basins. The economics of gas extraction was supported by the blended revenue stream from liquids extraction (i.e. oil). Dual revenue streams do not exist for coal-seam gas. To summarise, the cost of producing gas on Australia's east coast has materially increased. 
Pricing is now no longer just a function of domestic production costs and demand. The development of LNG export capability has 'linked' domestic gas pricing with global LNG market pricing. It is important to note that around $70-80 \%$ of LNG traded globally is supplied through the equivalent of long-term 'take-or-pay' contracts. The revenue from these contracts underwrites the lumpy upfront capital investment required to build the LNG terminals. International LNG pricing cannot be directly compared to the cost of domestic production or pricing on the Australian eastcoast. This is because the price of LNG does not include the cost of other key components of the supply chain that need to be incurred before the gas can be consumed. These include the avoidance of liquefaction and pipeline transportation of the gas to the point of consumption. An LNG exporter will theoretically be indifferent to an overseas buyer or a domestic customer if these costs are considered.

Table 3: Global gas reserves

\begin{tabular}{cccc}
\hline & Reserves in & Change since & Reserves to Production \\
& 2016 & $1996(\%)$ & Ratio \\
\hline North America & 11.1 & 31.5 & 11.7 \\
South America & 7.6 & 27.0 & 42.9 \\
Europe and Eurasia & 56.7 & 42.4 & 56.7 \\
Middle East & 79.4 & 61.5 & 124.5 \\
Africa & 14.3 & 40.2 & 68.4 \\
Asia Pacific & 17.5 & 76.5 & 30.2 \\
World & 186.6 & 51.1 & 52.5 \\
\hline
\end{tabular}

There has been a seismic shift in global gas markets in recent years. Reserves have increased substantially as a result of the development of new drilling technology. Despite global consumption growing by $58 \%$ since 1996 , reserves have broadly kept pace with a total increase of around $51 \%$. Table 3 shows proven gas reserves in 2016, the change in reserves over the past ten years and the current reserves to production ratio (i.e. the number of years of current consumption it would take to deplete proven reserves). Pricing of natural gas has subsequently fallen significantly in many markets as a consequence of much higher supply. 
Figure 2: LNG Japan and US Henry Hub Pricing

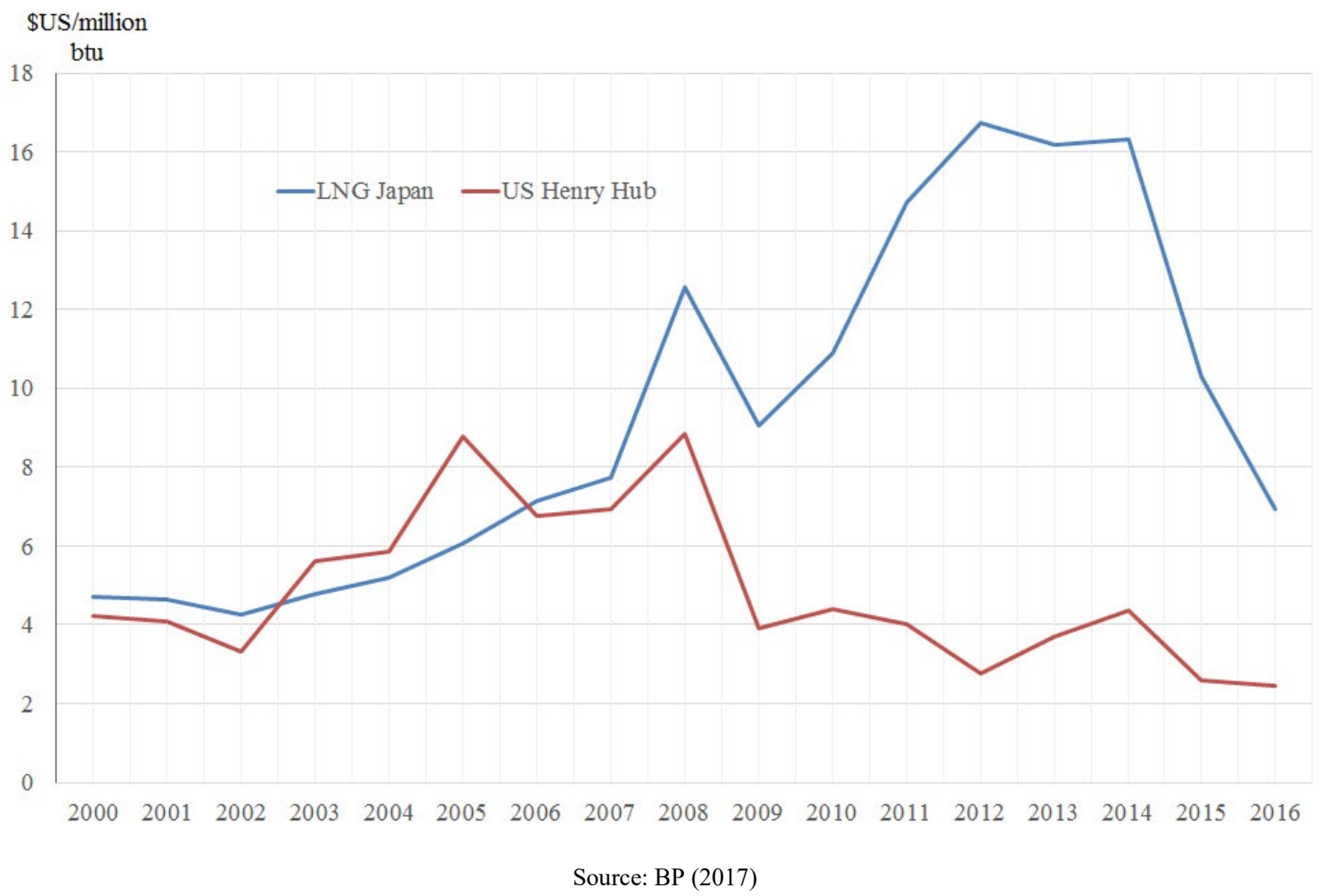

Figure 2 shows LNG pricing in Japan and the commonly cited US Henry Hub (a gas trading hub) gas price since 2000 . There are two trends worth noting. Firstly, the rapid run up in prices from 2005 to 2014 that led to the development of significant LNG production capacity globally, including the three lumpy LNG projects at Gladstone. Secondly, the increase in 'lumpy' LNG global production capacity resulted in a steep downward trend in pricing over the past few years. It should be noted that a further 61.95 million tonnes per annum of capacity is scheduled to come online in the US alone by 2019. As such, there may be little reason to assume LNG prices will trend upwards and could in fact become lower. Most importantly, LNG pricing outcomes are beyond the control of Australian policy makers (see Xunpeng et al, 2017) and have instead been found to be driven by global production volumes and costs, oil prices and industrial gas consumption (see Ponce and Krone, 2014). IGU (2016, p. 15) states: 'Lower oil prices may have decreased the spread between oil-linked and US LNG contracts in the near-term, but the lower starting point of US prices and abundant downside market fundamentals risks mean that US LNG contracts may offer buyers reduced price volatility over the next few years. ' Many commentators are aligned around this 'lower for longer' view of LNG pricing.

So while the east-coast has enough gas to physically satisfy demand, it is questionable whether demand can be met in the next few years if there is a subdued outlook for LNG pricing. Recall from Table 1 that approximately only one-fifth of $2 \mathrm{P}$ reserves are in 'operation' and able to be produced. With this taken into account, the ratio of reserves to demand falls substantially to just 5 years. There is a need for significant investment to expand Australia's gas production capability through drilling and other activities (to shift undeveloped 2P reserves into production). But if subdued pricing for LNG globally persists, gas producers have little incentive (and cash flow and balance sheet strength) to finance expansion of production. 
Expanded production is generally financed at times of high global demand with a buoyant medium-term outlook for oil and gas pricing. There is therefore a significant temporal issue associated with Australia's east-coast gas market. While the adequacy of gas resources is theoretically satisfied, real-world financing constraints associated with Australia now being 'linked' to the global LNG market create risks that resources may not be brought to market in a sufficiently timely manner. ${ }^{8}$ In fact, domestic production is expected to decline over the coming years from some basins. AEMO (2017) is expecting production from Victorian facilities to decline by $38 \%$ between now and 2021 . The number of wells being drilled halved from 1,534 in 2014 to 821 in 2015.

It is not just the subdued outlook for LNG pricing which is hampering exploration and production. Several states have introduced moratoria on the exploration and production of unconventional gas. Lewis Grey Advisory (2016, p.16) notes: 'Barriers to CSG development, in the form of Government moratoria and opposition by local activists, have intensified, particularly in NSW. Consequently, in all NSW CSG Basins (the Clarence Morton, Gloucester, Gunnedah, Hunter and Sydney basins) some or all reserves have been declassified and development has slowed down or stopped. AGL recently announced the abandonment of its Gloucester Basin Project on the grounds that expected gas production rates are sub-economic and Santos has reclassified its Gunnedah $2 P$ reserves as $2 C$ contingent resources.'

Analysing daily demand and supply is also instructive for assessing the challenges associated with the east-coast gas market. Domestic peak gas demand in recent times has reached 2,133 Terrajoules (TJ) per day. Gas-fired electricity generation has driven significant increases in domestic gas consumption with the retirement of Hazelwood and Northern coal-fired power stations requiring up to 1,200 TJ per day (see Finkel et al, 2017; AEMC, 2016; and Nelson et al, 2017). This is all in addition to the maximum demand of the LNG trains reaching 3,700 TJ per day. Total peak gas demand has already climbed to 6,321 TJ per day. There is a material gap between total output and domestic consumption added to contracted LNG demand. This is having non-trivial implications for short-term gas pricing. The growth in daily demand and the gap between output and contracted consumption is shown in Figure 3.

\footnotetext{
${ }^{8}$ This is particularly problematic given the shift towards gas production from CSG. Unlike conventional wells where significant capital expenditure is made up front for production over several decades, CSG requires ongoing investment to maintain current levels of production.
} 
Figure 3: Daily east-coast gas demand

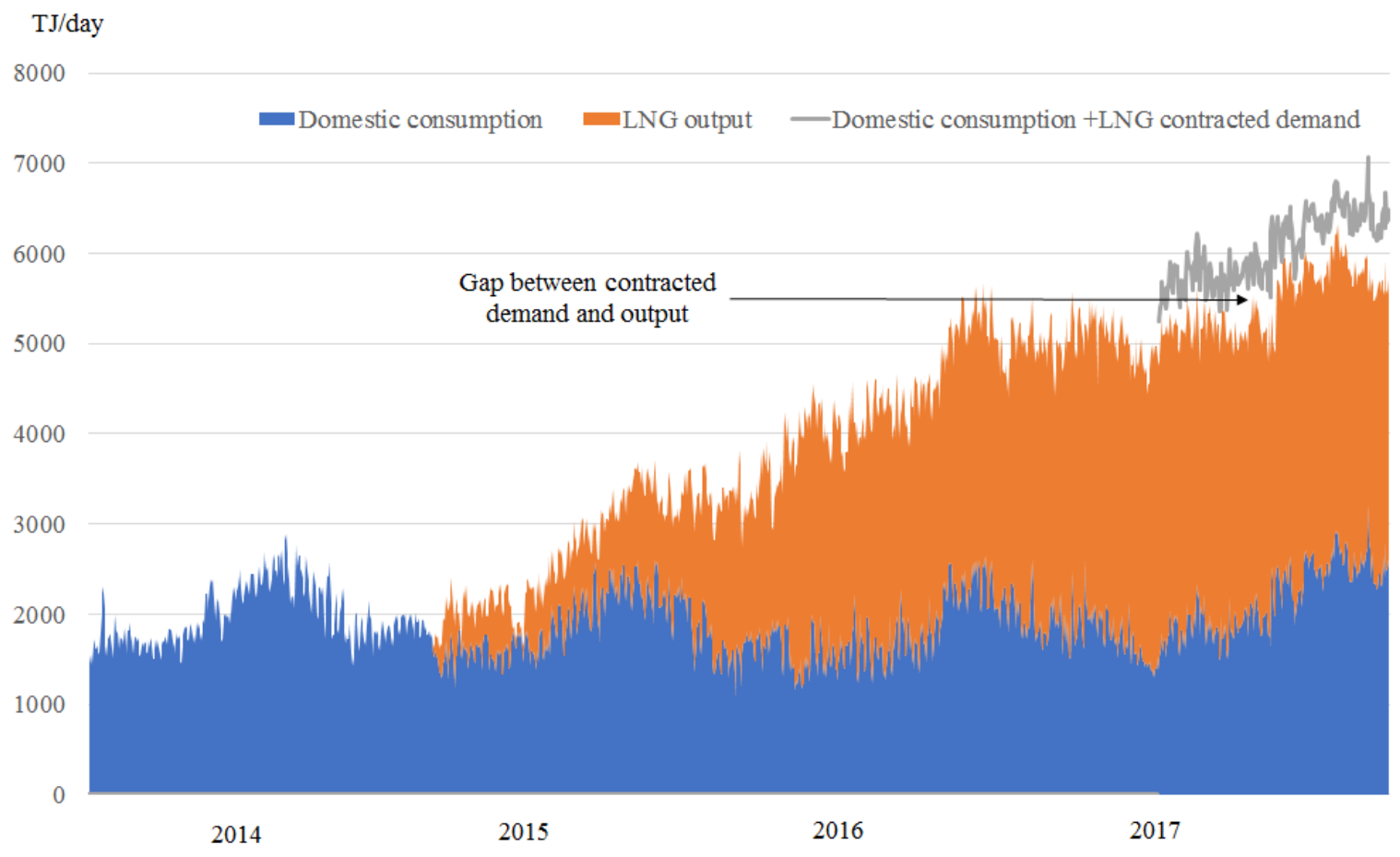

Source: Industry data

The theoretical production capability of the east-coast market is around 7,000 $\mathrm{TJ}$ per day (see Figure A1 in Appendix 1). Given the decline in production associated with Victorian fields is forecast to be up to $40 \%$, the market is more likely to have a theoretical production of closer to $6,000 \mathrm{TJ}$ per day by the end of the decade. There is therefore a very tight daily market with theoretical demand from LNG exporters of around 4,000 $\mathrm{TJ}$ per day, up to 3,000 $\mathrm{TJ}$ per day of domestic demand (industrial, gas-fired generation and residential) and only 6,000 $\mathrm{TJ}$ per day of production capability. And this ignores the spatial constraints associated with pipeline transportation limitations. It is therefore little surprise that AEMO (2017) has forecast shortfalls of supply of up to $107 \mathrm{PJ}$ per annum in $2018 .^{9}$

\footnotetext{
${ }^{9}$ There is some discussion about potential new sources of supply. In August 2017, Cooper Energy secured \$265 million of loans and commenced a $\$ 135 \mathrm{~m}$ equity raising to fund development of the $24 \mathrm{PJ}$ per annum Sole gasfield in Victoria's offshore Gippsland Basin Exxon Mobil has also announced it has secured potentially 2 trillion cubic feet of new gas on the edge of the continental shelf called Dory off Victoria's coast. However, such exploration is yet to result in increases in booked 2P reserves (Chambers, 2017).
} 
Page 9 
Wholesale gas prices have more than doubled since 2014 (see Figure A2 in Appendix 1). The Australian Industry Group (AI Group, 2017) surveyed its industrial membership base and found that: increases in electricity and gas prices will cost energy users between $\$ 10-\$ 12$ billion per year; some businesses were questioning their ongoing economic viability due to higher energy prices; long-term gas contracts were becoming harder to obtain; and one to two year wholesale contract pricing was in some cases $\$ 20$ per GJ or higher. The Australian Competition and Consumer Commission (ACCC, 2017, p. 42) has reinforced this conclusion by stating, 'Commercial and Industrial (C\&I) users told the ACCC that they are experiencing difficulties in securing offers on competitive terms for supply of gas for 2018 and beyond. Most large C\&I users had only one supplier willing to supply them and prices offered in 2017 were considerably higher than 2016 levels, generally ranging from \$10-16/gigajoule (GJ). These prices are well in excess of appropriate benchmark prices. ${ }^{10}$

The lumpiness of LNG export capability has resulted in a structural change in the east-coast gas market. However, practices within the industry have not evolved at the necessary pace. This is perhaps best summarised by a prominent industry leader and economist (Stevens, 2017, p. 30): "It is well understood that as international commodity markets grow, with more suppliers and more customers, the length of contracts tend to shorten and the price of the commodity is set by the market instead of bilateral negotiations. This is what we have already seen happen in the LNG market. So what is the problem with natural gas prices in Australia? We know that local production is smaller than the sum of export commitments and domestic consumption, and so the local price does not clear to international prices and hence incredible local price spikes result. Today we can see contracts more than 100 per cent higher than the spot Chinese price."

\section{Theoretical partial equilibrium model of the east-coast gas market}

In this Section, a simple theoretical partial equilibrium model of the east-coast gas market is established. The purpose of this model is to explore the impact of both high and low international LNG pricing on the domestic east-coast gas market. It is assumed that east-coast Australian gas producers cannot influence the international LNG price. Therefore, the export price $\left(\mathrm{P}^{\mathrm{W}}\right)$ is assumed to be exogenous and is the LNG netback price - the international LNG price minus the costs of liquefaction, shipping and regasification. A domestic gas consumption function is presented in Equation 1, with the elasticity of demand $(m)$ assumed to be negative and linear for simplicity.

$P^{D}=\beta-m D$

The aggregate supply function is presented in Equation 2, with the elasticity of supply (n) assumed to be positive and linear for simplicity. The linear approach can be contrasted with the estimated supply curve presented in Figure 1. Figure 1 shows $2 \mathrm{C}$ reserves are thought to be much more costly to develop and produce than current $2 \mathrm{P}$ reserves (both developed and undeveloped).

$$
P^{S}=\alpha+n S \quad \text { where } S=f\left(N P V \sum_{t+1}^{\infty} E P^{W}\right)
$$

\footnotetext{
${ }^{10}$ The ACCC estimates 'benchmark prices' to be around $\$ 5.87 /$ GJ in Queensland and up to $\$ 7.77 /$ GJ in the Southern States. The ACCC has stated that the appropriate benchmark price in Queensland for 2018 is the higher of the LNG netback price (based on expected Asian LNG spot prices) and the cost of production of the marginal supplier in Queensland. 
An important element of Equation 2 is that supply is a function of the expected export price $\left(\mathrm{EP}^{\mathrm{W}}\right)$. If global LNG prices fall significantly and the outlook is subdued, producers will not expand exploration and production. The time-lag between such spending and supply manifesting in the supply curve is likely to be several years. This allows the model to explain the lack of investment in drilling activity despite domestic gas prices today seemingly warranting it.

A set of equilibria is presented in Figure 4 for an initial scenario where the east-coast gas market becomes exposed to a relatively high global LNG price for the first time. This is presented as the 'base-case' analysis as such a scenario represented the business case for the development of LNG export facilities. Even at relatively low oil prices (e.g. \$US65 a barrel), the implied LNG price at Gladstone is $\$ 12.40$ per GJ (Credit Suisse, 2017). Ex-transport costs this is materially higher than the expected domestic cost of production and historic east-coast gas prices of \$3-5 per GJ.

Figure 4: East-coast gas market equilibria with a relatively high global price

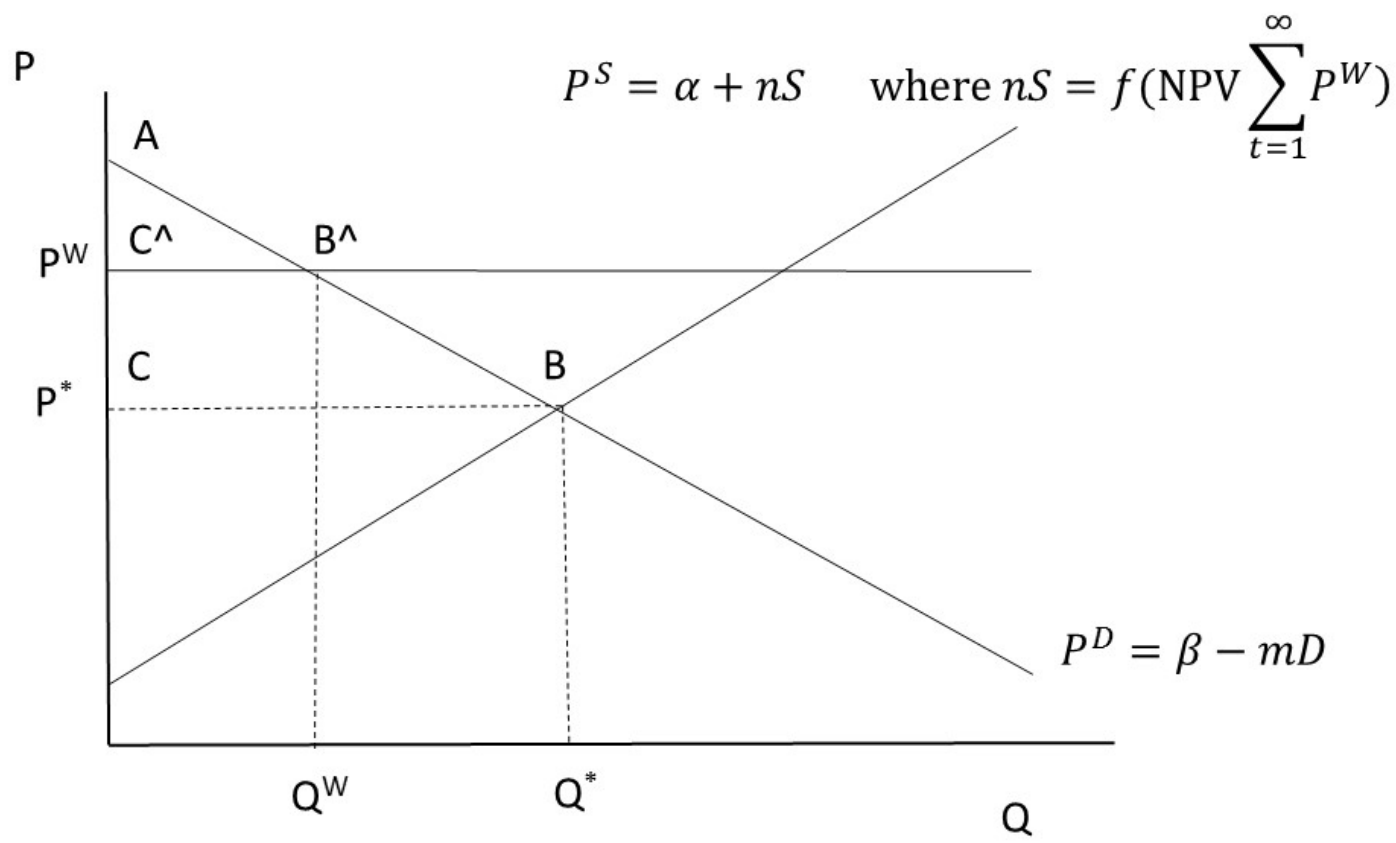

Figure 4 shows the equilibria associated with the east-coast gas market in a scenario where the global price $\left(\mathrm{P}^{\mathrm{W}}\right)$ is higher than the historic east-coast gas price $\left(\mathrm{P}^{*}\right)$. The domestic quantity consumed falls from $\mathrm{Q}^{*}$ to $\mathrm{Q}^{\mathrm{W}}$. Producers effectively preference international buyers as they are prepared to pay a higher price. The amount of consumer surplus decreases from the area bound by $\mathrm{ABC}$ to the area enclosed by $\mathrm{AB}^{\wedge} \mathrm{C}^{\wedge}$. The decrease in consumer surplus is more than offset by increases in producer surplus (as noted by Neill, 2017). 
Figure 5: East-coast gas market equilibria with a relatively low global gas price

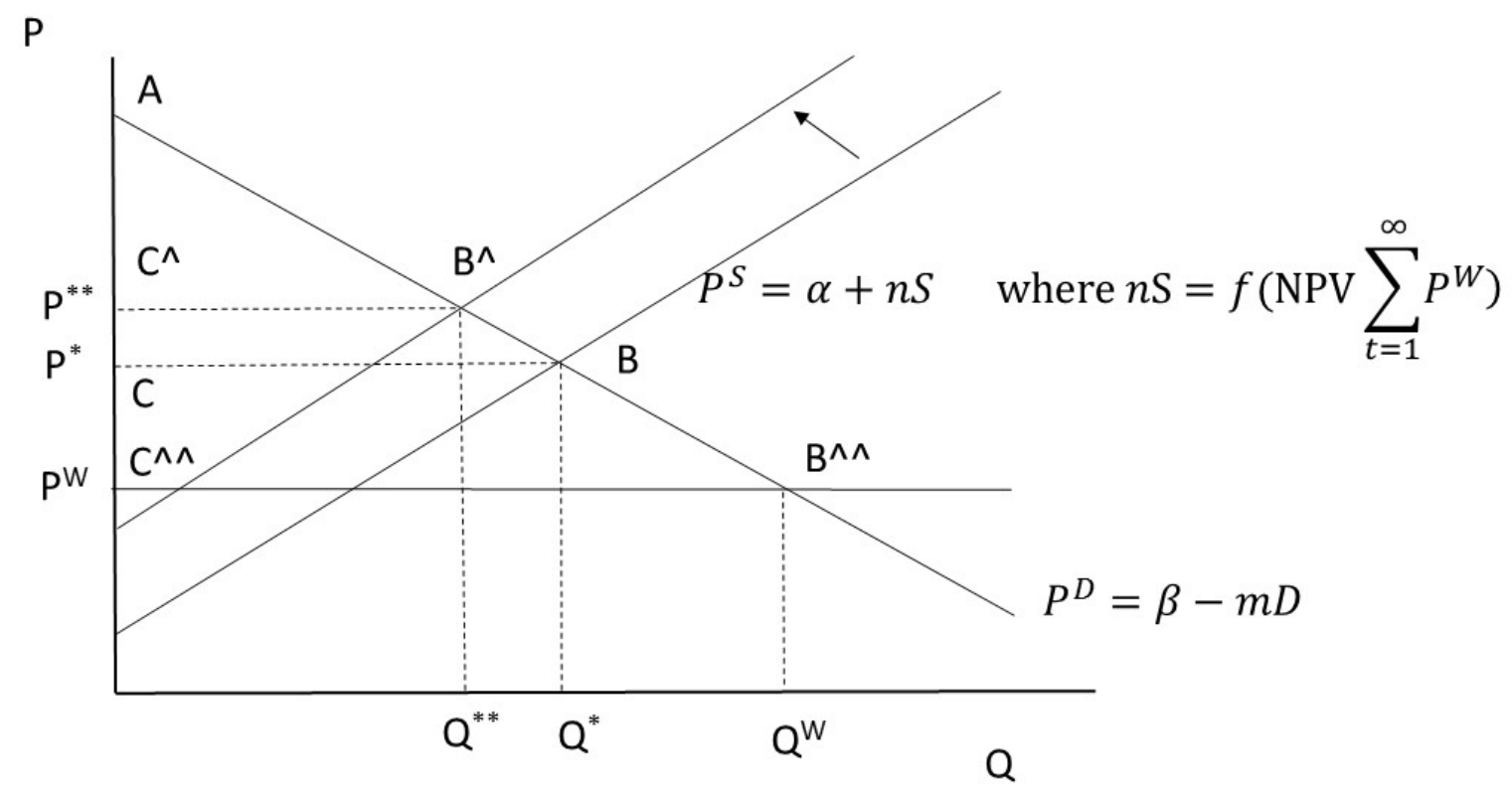

Figure 5 presents the second of the scenarios developed for this analysis. The global LNG price $\left(\mathrm{P}^{\mathrm{W}}\right)$ falls significantly below the previous domestic point of equilibria. As a consequence of the subdued outlook for global LNG prices, the aggregate supply curve shifts to the left as fewer $2 \mathrm{P}$ reserves are developed and brought to market. The quantity consumed falls to $\mathrm{Q}^{* *}$ and the price increases well beyond export parity pricing to $\mathrm{P}^{* *}$. Importantly, the price paid by domestic users is higher than the global price because there is no bi-directional import/export capability. Gas can be exported but not imported. Consumer surplus falls from the area bound by $\mathrm{ABC}$ to the area $\mathrm{AB}^{\wedge} \mathrm{C}^{\wedge}$. If domestic users were able to source international gas prices, it is worth noting that consumer surplus would expand from $\mathrm{AB}^{\wedge} \mathrm{C}^{\wedge}$ to $\mathrm{AB}^{\wedge \wedge} \mathrm{C}^{\wedge \wedge}$.

\section{Options for improving pricing outcomes for consumers}

The theoretical partial equilibrium framework in Section 3 is useful for assessing the various options that have been suggested as a means of improving pricing outcomes for domestic energy users. The four options that are assessed in this Section are: the Commonwealth Government's Australian Domestic Gas Security Mechanism; expanding supply; importing LNG; and expanding pipeline infrastructure to connect interstate gas reserves to the east-coast.

\subsection{Australian Domestic Gas Security Mechanism}

In 2017, the Commonwealth Government introduced the Australian Domestic Gas Security Mechanism. Under the policy, the Minister for Resources will be in a position to declare whether there is a 'shortfall' of gas across the east-coast market. LNG producers will be required to submit forecasts of production of their own gas and LNG production, including information about 'third-party' gas (i.e. gas they have bought, but not produced). An annual process is intended to fit within LNG shipment scheduling. Export licenses would be granted for the following calendar year. This requires accurate 12-18 month forecasts of gas volumes and prices (and related parameters including oil prices, LNG spot prices and the like). 
With regard to the high and low LNG price scenarios discussed in Section 3, the Australian Domestic Gas Security Mechanism would be expected to have little impact. Most domestic consumers (including retailers) would already have contracted at the prevailing price ( $\mathrm{P}^{\mathrm{w}}$ in the high global price scenario and $\mathrm{P}^{* *}$ in the low global price scenario). The Mechanism may force existing production to domestic utilisation but at lower volumes year after year as the supply curve continues to shift left.

\subsection{Expanding supply}

Expanding domestically produced supply appears at face value to be a logical solution to the issues currently facing the market. However, the two global pricing scenarios produce different results when considering expansion of supply. Much of the existing literature is based upon an arbitrage opportunity whereby a globally high gas price continues to incentivise the development of local supplies to the point where there is a domestic 'glut' caused by an export constraint at the LNG terminals. Due to the lumpy nature of LNG capital investment, this causes a price 'separation' whereby the time value of money incentivises the continued production of existing reserves to satisfy local demand at prices lower than the global LNG price. Figure 6 shows such a scenario (Simshauser and Nelson, 2015a, 2015b). 
Figure 6: Expanding supply in a market with high global gas prices

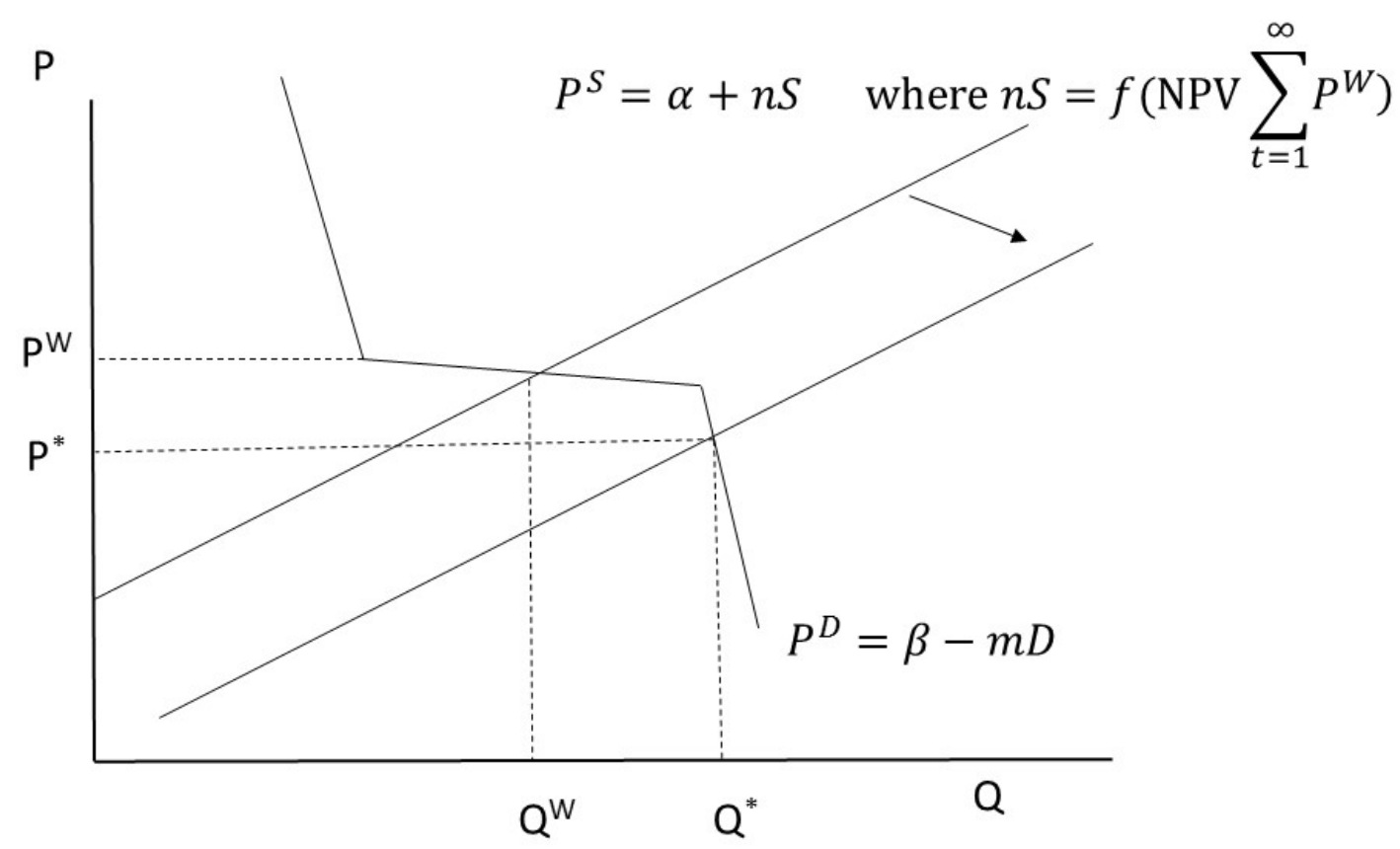

Figure 6 presents the conventional thinking about incentives for expanded supply in the context of high international gas pricing. While other commentators have presented alternative views (see Grundoff, 2013, as an example), little analysis has been completed on how supply would respond if LNG prices are comparatively low.

In a world of low global LNG pricing, there is a substantially different result from that projected by Simshauser and Nelson (2015a, 2015b). Supply cannot expand when the supply curve is a function of the expected future stream of diminishing revenue from global gas pricing. As a price taker, Australian LNG producers face little incentive to expand production domestically when there is a subdued outlook for global gas pricing. This is demonstrated by the supply curve shifting left in the second 'low global gas price' scenario shown in the preceding Section.

There is one other component of domestic gas production which requires consideration in an economic assessment of supply options. As noted in Section 2, the vast majority of $2 \mathrm{P}$ reserves on Australia's east-coast are now unconventional and, in particular, coal-seam gas. Coal-seam gas is largely 'inflexible' in the sense that wells are drilled and gas is then produced in a steady flow. It is more costly and difficult to regulate the flow to meet variable consumer demand. This is not necessarily a problem for LNG exporters who require a steady flow to fill LNG cargoes. Domestic consumption though is inherently seasonal and diurnal in nature which necessitates the use of additional storage and 'shaping' products to match CSG production with demand.

\subsection{Importing $L N G$}


Domestic gas retailers and industrial gas users are exploring options for accessing internationally priced gas (through importation as LNG) utilising facilities such as Floating Storage

Regasification Units (FSRUs). Internationally, FSRUs are increasingly being deployed to extract pricing arbitrage opportunities. The growth of LNG export capability has led to an increase in deployment of FSRUs to facilitate importation. In fact, 12 of the last 18 countries to commence gas importation have utilised FSRU technology (see LNG-Worldwide, 2017). There is currently around 30 million tonnes per annum of FSRU capacity scheduled to be completed by $2020 .{ }^{13}$

13 This is approximately 1,500 PJ of gas, around the same volume the three large LNG gas projects at Gladstone are exporting annually. 
In an environment with comparatively high international gas pricing, it would be improbable for an FSRU to be utilised. However, in an environment of relatively low international gas pricing, an FSRU of considerable capacity (relative to domestic gas consumption) may play a critical role in eliminating price differentials between Australian and international markets. The theoretical partial equilibrium model in Section 3 shows that the price paid by domestic users is higher than the global price because there is no bi-directional import/export capability. Gas can be exported but not imported. Consumer surplus falls from the area bound by $\mathrm{ABC}$ to the area $\mathrm{AB}^{\wedge} \mathrm{C}^{\wedge}$.

Assuming import infrastructure of sufficient capacity is forthcoming, domestic gas users would be able to source gas at international gas prices plus regasification and transportation costs. Assuming these are minimal, consumer surplus would expand from $\mathrm{AB}^{\wedge} \mathrm{C}^{\wedge}$ to $\mathrm{AB}^{\wedge} \mathrm{C}^{\wedge \wedge}$. The 'price floor' becomes the 'price cap'. The lumpiness of capital and temporal misallocation is overcome by linking the relatively small domestic gas market with much larger and liquid international LNG pricing. In fact, in a market with relatively high domestic gas production and transportation costs, consumer surplus is maximised by the importation of gas. It is arguable that this is currently the case in the Australian east-coast gas market. Credit Suisse (2017, p.1) has argued that, '..at US\$60 per barrel of oil, LNG could be imported in Victoria $>$ A $\$ 2.50 /$ GJ below gas transported from Queensland.'

\subsection{Significant pipeline investment connecting interstate gas reserves}

While there is a very tight gas demand/supply balance on Australia's east-coast, there are considerable comparatively lower cost reserves on Australia's west-coast. Around 2,800 PJ of gas is exported annually, almost double the size of Australia's east-coast LNG export facilities. The contrast in market outcomes has resulted in public commentary about the merits of developing a transcontinental pipeline to 'link' the east-coast and west-coast markets physically and financially. It is worth noting that the Western Australian Government has imposed a 15\% gas reservation policy which is thought to reduce economic welfare (see Neill, 2017).

Some preliminary estimates of the cost of building such a pipeline indicate it would be uneconomic when compared to importation infrastructure, although the outcomes in the partial equilibrium model in Section 3 would be the same. It could require capital investment of approximately $\$ 5$ billion to facilitate carriage of $\sim 100 \mathrm{PJ}$ per annum. To justify the significant capital expenditure, pipeline tariffs would need to recover $\$ 500$ to 600 million per annum to produce an acceptable economic return. Transporting Western Australian gas to Victoria, pipeline tariffs would approximate $\$ 7.50$ per GJ (around \$6 per GJ for transportation to Moomba and a further $\$ 1.50$ per GJ from Moomba to Melbourne). These costs are clearly prohibitive when compared with importation infrastructure. Assuming shipping and liquefaction costs of around $\$ 1.70$ per GJ and $\$ 1.50$ per GJ for life cycle import terminal costs, the 'equivalent' tariff for FSRU would be around $\$ 3.20$ per GJ. This is less than half the estimate for constructing a transcontinental pipeline.

\section{Policy considerations and concluding remarks}

Simshauser (2017) states that the LNG resources boom in Queensland is likely to generate significant economic benefits. The Reserve Bank of Australia concluded that the broader resources boom in the 2000s has significantly benefited Australia: 'boosting real per capita household disposable income by 13 per cent by 2013' (Downes et al. 2014, p. i). The same research highlights that Australia has largely avoided de-industrialisation and a decline in industries such as trade-exposed manufacturing caused by a high Australian dollar - a phenomenon known as 'Dutch Disease'. 
This paper has considered the unintended negative consequences of the 'lumpiness' of capital allocation to develop the LNG export industry and the temporal instability caused by a seismic shift in global oil and gas pricing. The significant economic detriment being caused by these issues, manifesting through domestic gas supply shortfalls and comparatively high domestic gas prices, is only now being understood by policy makers (see Grafton et al, 2018).

Contrary to recent Australian policy developments, this paper finds that the 'no regrets' policy would be to allow market participants to develop gas import infrastructure. Such a development would ensure that the market price floor (created by LNG export capability) is also the market price cap. Import infrastructure would create a bidirectional export/import capability across eastcoast gas markets and would be likely to significantly improve market liquidity, price transparency and the development of new financial hedging instruments. This aligns with the view of Egging and Holz (2016) and Dorigoni et al (2010) that LNG is preferred as a hedging option in facing uncertain events.

Most importantly, development of gas import infrastructure would not involve government intervention and could therefore limit perceptions of sovereign risk that have emerged due to the implementation of the Australian Domestic Gas Security Mechanism. In the event that international oil and gas prices markedly increased, the economic risk associated with a stranded asset would sit with proponents of gas import infrastructure and not domestic gas users and producers. 


\section{References}

Australian Industry Group: AI Group. (2017), Energy shock: no gas, no power, no future?, AI Group Publication, February 2017.

Australian Competition and Consumer Commission: ACCC. (2017), 'ACCC Gas Inquiry 20172020, Interim Report', ACCC Report, Melbourne.

Australian Energy Market Operator: AEMO. (2017), 2017 Gas Statement of Opportunities, AEMO Publication, Melbourne.

Australian Energy Market Commission: AEMC. (2016), 'Interim Report: System Security Market Frameworks Review', AEMC Publication, Sydney.

BP. (2017), BP Statistical Review of World Energy 2017, BP Publication, London.

Chambers, M. (2017), 'Santos to cap Gladstone gas exports', The Australian, 25 August 2017, p. 22.

Christie, V. Mitchell, B. Orsmond, D. and Van Zyl, M. (2011), 'The Iron Ore, Coal and Gas Sectors', RBA Bulletin, March, pp 1-7.

Credit Suisse. (2017), Australian East Coast Gas, Credit Suisse Analyst Report, 8 August 2017.

De Silva, P. Simons, S. and Stevens, P. (2016), 'Economic impact analysis of natural gas development and the policy implications', Energy Policy, Vol. 88, pp. 639-651.

Dorigoni, S. Graziano, C. and Pontoni, F. (2010), 'Can LNG increase competitiveness in the natural gas market?', Energy Policy, Vol. 38, No. 12, pp. 7653-7664.

Downes, P. Hanslow, K. and Tulip, P. (2014), 'The Effect of the Mining Boom on the Australian Economy', Reserve Bank of Australia Research Discussion Paper, No. 201408 .

Egging, R. and Holz, F. (2016), 'Risks in global natural gas markets: Investment, hedging and trade’, Energy Policy, Vol. 94, pp. 468-479.

Finkel, A. Moses, K. Munro, C. Effney, T. and O'Kane, M. (2016), Independent Review into the Future Security of the National Electricity Market: Preliminary Report, Commonwealth Government Publication, Canberra.

Grafton, Q. Xunpeng, S. and Cronshaw, I. (2018), "'Making Cents" of the Eastern Australian Gas Market', Economic Papers, Vol. 37, No. 1, pp. 42-54.

Grundoff, M. (2013), 'Cooking up a price rise - will CSG exports push up the price of gas?', Australia Institute Policy Brief, No.53, The Australia Institute, Canberra.

Jacobs, D. (2011), 'The Global Market for Liquefied Natural Gas', RBA Bulletin Article, September Quarter, Sydney.

Lewis Grey Advisory. (2016), 'Projections of Gas and Electricity Used in LNG: Public Report', Report prepared for AEMO, Brisbane. 
Neill, K. (2017), 'Western Australia's Domestic Gas Reservation Policy: The Elemental Economics', Economic Papers, Vol. 36, No. 2, pp. 121-134.

Nelson, T. Bashir, S. McCracken-Hewson, E. and Pierce, M. (2017), 'The Changing Nature of the Electricity Industry', Economic Papers, Vol. 36, No. 2, pp. 104-120.

Ponce, M. and Krone, V. (2014), 'LNG Pricing Differences Across the Atlantic - a Comparison Between the United States and Europe', Presentation to IAEE Conference on Energy and the Economy, New York, June.

Simshauser (2017), 'Australia's National Electricity Market: decarbonisation in a hostile policy environment', Griffith University Working Paper, Griffith University, October 2017.

Simshauser, P. and Nelson, T. (2015a), 'Australia's coal seam gas boom and the liquefied natural gas entry result', Australian Journal of Resource and Agricultural Economics, Vol. 59, No. 4, pp. $1-22$.

Simshauser, P. and Nelson. T. (2015b), 'The Australian east coast gas supply cliff', Economic Analysis and Policy, Vol. 45, No. 1, pp. 69-88.

Stevens, M. (2017), 'Untruths fuel 'gas price of desperation', The Australian Financial Review, 25 August, 2017, p. 30.

Wood Mackenzie. (2017), 'Lower for longer LNG prices: market outlook', Wood Mackenzie Publication, June 2017.

Xunpeng, S. Malamakkavu, H. and Tao, J. (2017), 'Global impact of uncertainties in China's gas market', Energy Policy, Vol. 104, pp. 382-394. 
Appendix 1: Daily production and wholesale gas pricing

Figure A1: Aggregate daily production supply curve

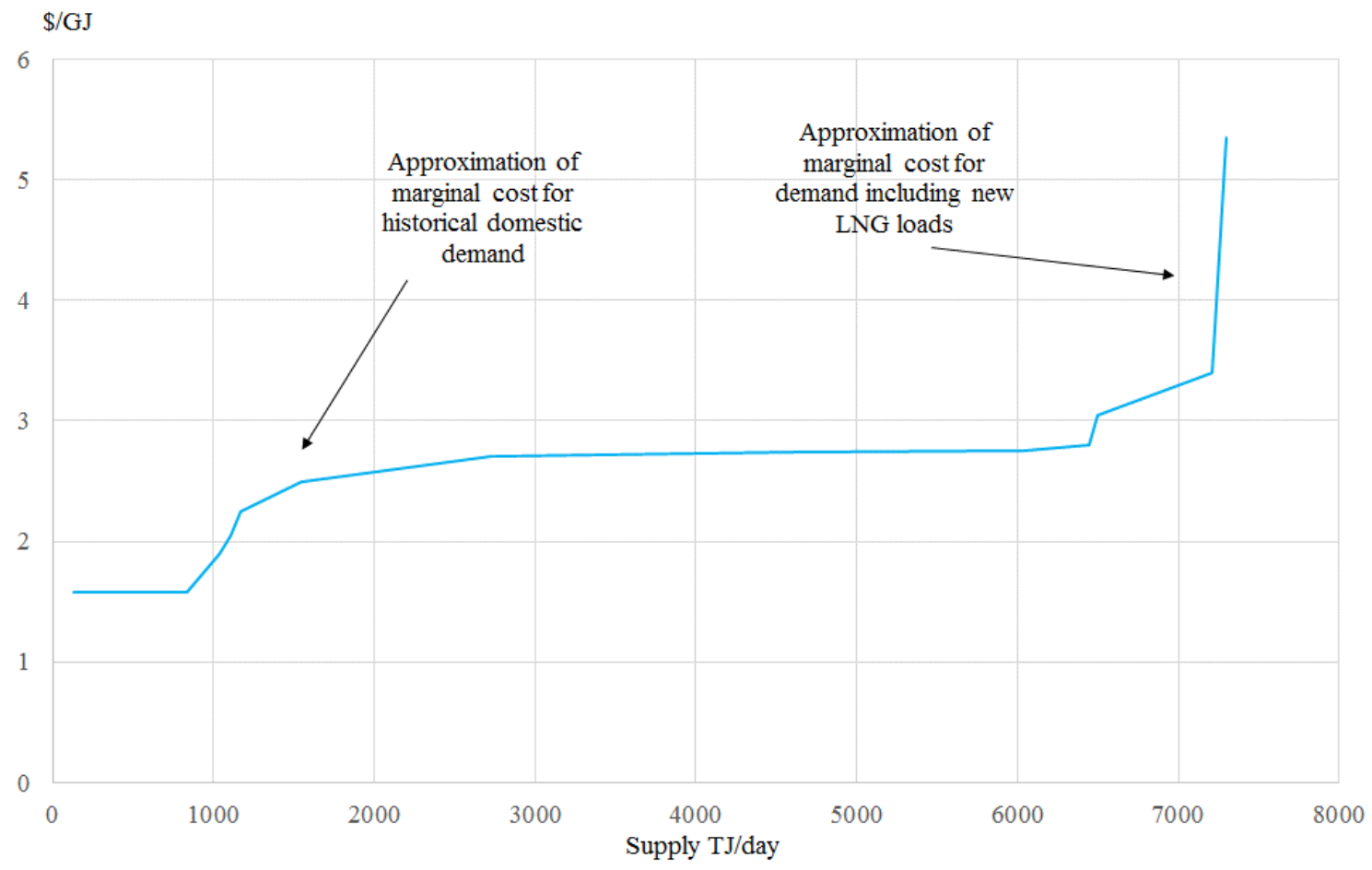

Source: Compiled using data from AEMO (2017) and industry sources

Figure A2: Wholesale gas pricing

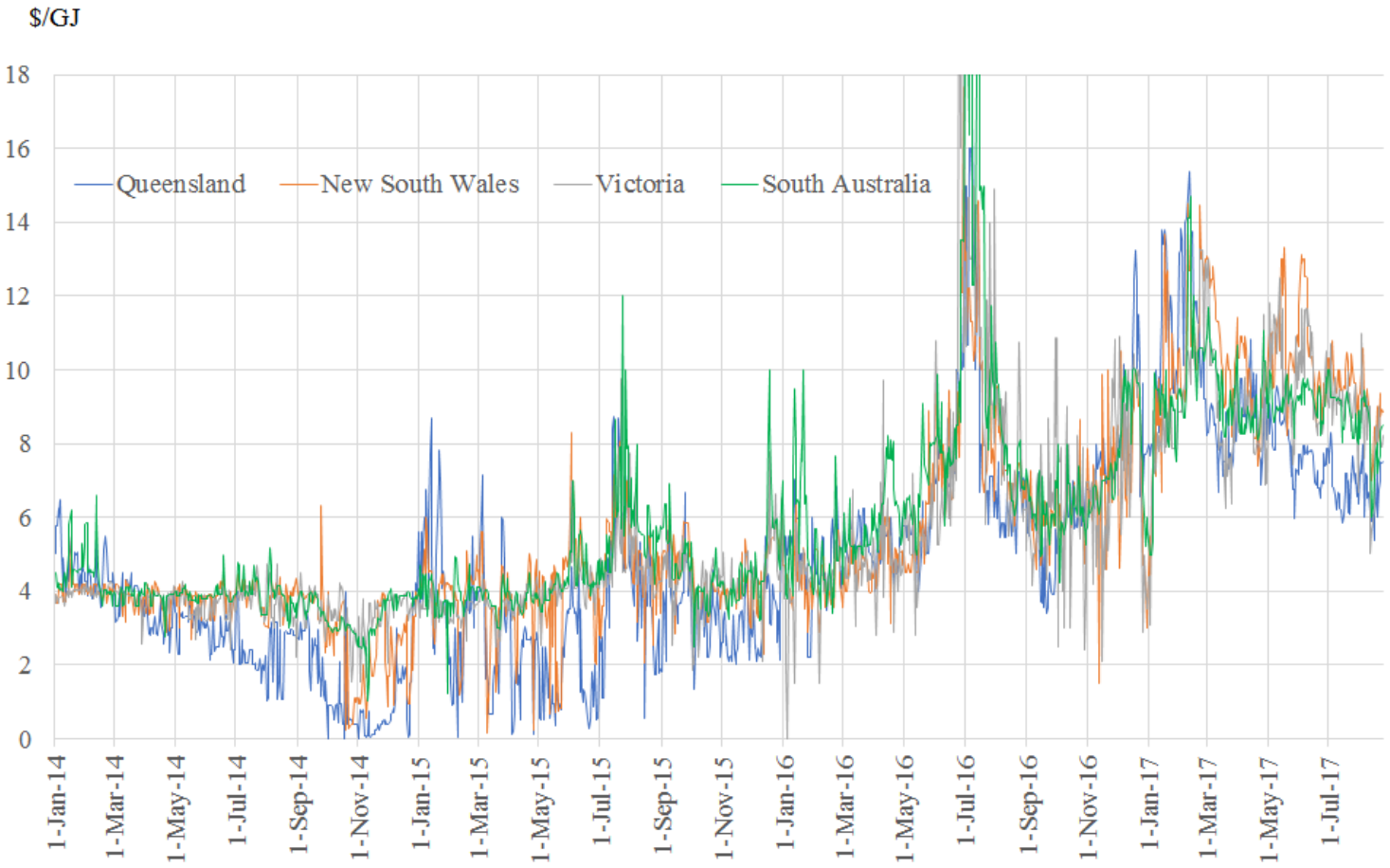

Source: Compiled using data from AEMO 